Article

\title{
Reconsidering Richard Rorty’s Private-Public Distinction
}

\section{Lior Erez}

Department of Political Science, School of Public Policy, University College London, 29/30 Tavistock Square, London WC1H 9QU, UK; E-Mail: lior.erez.10@ucl.ac.uk

Received: 25 March 2013; in revised form: 2 May 2013 / Accepted: 8 May 2013 /

Published: 13 May 2013

\begin{abstract}
This article provides a new interpretation of Richard Rorty's notion of the private-public distinction. The first section of the article provides a short theoretical overview of the origins of the public-private distinction in Rorty's political thought and clarifies the Rortian terminology. The main portion of the article is dedicated to the critique of Rorty's private-public distinction, divided into two thematic sections: (i) the private-public distinction as undesirable and (ii) the private-public distinction as unattainable. I argue that Rorty's formulation provides plausible answers to the first kind of criticism, but not to the second. Finally, a reformulation of the private-public distinction will be suggested, which both mitigates the second line of criticism and better coheres with Rorty's general theory.
\end{abstract}

Keywords: Rorty; Richard; pragmatism and neo-pragmatism; public-private distinction; liberalism

\section{Introduction}

Philosophers do not often provide a narrative of their own intellectual development as a coming-of-age story. Richard Rorty might be one exception to this rule. The title of his autobiographical paper, "Trotsky and the Wild Orchids", refers to his two main interests as a young man: on the one hand, the search for social justice, as conceived by his parents and their socialist-Trotskyite milieu; and on the other hand, the search for sublimity and liberty, exemplified by his obsession for the orchids he discovered during the family's summers in north-west New Jersey. Desperate to find a reconciliation of the just and the sublime, Rorty first turned, albeit half-heartedly, to religion and, finally, settled for philosophy, where he believed his commitment towards social justice and his intellectual curiosity might reinforce each other. Slowly, he became disenchanted with the promise of analytical philosophy and more attracted to continental philosophers, like Hegel and Nietzsche, and, above all, the 
Pragmatism of John Dewey. "I decided that the hope of getting a single vision by becoming a philosopher had been a self-deceptive atheist's way out”, he writes, "so I decided to write a book about what intellectual life might be like if one could manage to give up the Platonic attempt to hold reality and justice in a single vision” ([1], pp. 12-13).

It was that book, Contingency, Irony and Solidarity (CIS), which cemented Rorty's transition from the philosophy of mind and language to political and moral theory. While his previous writings have only hinted at the social and political implications of his seminal work, Philosophy and the Mirror of Nature (PMN), CIS dealt directly with those implications, aiming to provide an answer to the question: is it possible to have both individual liberty and social justice, both the orchids and Trotsky? Rorty's answer, in brief, was “yes, but not at the same time”. The attempt to hold justice and sublimity in one theoretical vision is futile, as they are incommensurable. It is nevertheless possible for one person to be, in alternate moments, Friedrich Nietzsche and John Stuart Mill, but the first self should be restricted to the private sphere and the second to the public sphere.

The purpose of this paper is to provide a critical reading of Rorty's notion of the private-public distinction. My intention is not only to consider Rorty's own writings on this issue, but also to provide an analytical discussion of the numerous critiques this distinction has received. Rorty was considered a provocative and controversial thinker, even before his turn to political theory, but it is still surprising to see how widely his critics range: from radical poststructuralists and Marxists to feminists and conservatives and, not least, his fellow pragmatists. I would like to argue that most of these critiques can be shown to be answered from within Rorty's theory, while some of them, along with insights derived from his later writings, require a reformulation of Rorty's arguments.

The first section of the paper will provide a short theoretical overview of the origins of the public-private distinction in Rorty's political thought and will clarify the oft-idiosyncratic Rortian terminology. The main portion of the paper will be dedicated to the critique of Rorty's private-public distinction, divided into two thematic sections. The first line of criticism is that the private-public distinction is undesirable, while the second is that it is unattainable. These two positions are not mutually exclusive and some critics hold both, sometimes in the same argument. Nevertheless, it is my contention that this mode of analysis is useful, as Rorty's formulation can provide answers to the first line of criticism, but not to the second. Finally, a reformulation of the private-public distinction will be suggested, which both mitigates the second line of criticism and better coheres with Rorty's general theory.

\section{Rorty’s Political Project: An Overview}

Rorty's political project arguably can be described as a direct continuation of his critique of analytical philosophy in PMN-in a sense, the first chapter of CIS picks up where PMN left off [2,3]. In his earlier critique, Rorty attacked Western philosophy's visual metaphors of knowledge as representation of truth. He argued for a separation between the notions of truth and justification, claiming that "capital $\mathrm{T}$ truth" could never be reached and that we should suffice with justifying our beliefs to our fellow speakers. Truth becomes "what our peers will, ceteris paribus, let us get away with saying” ([4], p. 176). CIS continues to describe what Rorty calls "the contingency of language", arguing that we can never provide external criteria for arguing that one "vocabulary" is preferable to 
another. The languages of the natural sciences, psychology, literature, etc., are partly defined as distinct languages, because each has its own criteria by which we determine the truth-value of a statement. These languages are incommensurable. Instead of trying to find a single set of criteria for truth external to the discourse, Rorty suggests that we should think of language as an army of metaphors and of conversation as an attempt to make one's interlocutor accept these metaphors [5,6].

This point of departure allows Rorty to move on and discuss the implications of the contingency of language for the image of the self and for the political community. First, he reiterates his non-essentialist view of the self as a web of beliefs and vocabularies [7]. Rorty argues that the rationalistic image of the self should be substituted by an aesthetic one. Autonomy should be understood not as a static fact that constitutes our "authentic" self, but as a process of self-creation, of creative redescription of the world on one's own terms. The ideal figure of this aestheticised culture, the ironist, is always aware of the contingency of her vocabularies and, therefore, constantly strives to create new descriptions of the world [5]. Rorty's next line of argument is that "our” liberal political institutions, though historically contingent, can be seen as optimal, because they grant each of us maximal freedom for self-creation, since they have "no ideal except freedom" [5]. Rorty adopts Judith Shklar's definition of a liberal as someone who sees cruelty as the "worst thing we can do" and argues that diminishing cruelty and humiliation should be the primary goal of politics. Liberal democracy, if it can rid itself of the philosophical baggage of the Enlightenment and become aware of its own contingency, is for Rorty the optimal way for society to structure social life.

What still needs to be clarified is the relation between self-creation and diminishing cruelty (what Rorty terms "solidarity”). In an influential paper, Nancy Fraser argues that Rorty had changed his views on this issue over the years [8]. First, Rorty advocated a sort of "invisible hand" approach. If left to their own creative practices, "poets" and ironists would provide society with ever newer and more sensitive metaphors, which would develop society's sensitivity to more and more kinds of cruelty: in other words, according to Fraser's reading, Rorty thought that poets would be led-as if by an invisible hand-to develop a culture of increasing empathy. ${ }^{1}$ Our liberal culture is only the way it is because of the empathetic vocabulary of poets, like Christ, Wollstonecraft, Mill and Marx. Fraser argues that Rorty later changed his mind, realising that some poets, in their quest for sublimity, would care little for the suffering of others. They would in fact be antithetical to the goal of solidarity, as they might try to coerce their redescriptions on others. It might appear that if liberals see cruelty as the worst of evils, the freedom of self-creation must be restricted.

While I disagree with Fraser's narrative of "early" and "late" Rorty-in fact, all of these conceptions can be found within CIS - I nevertheless take her reading to be a reasonable one of the different aspects of Rorty's thought. Rorty, however, refuses to choose between self-creation and solidarity. Instead, he argues that the idea that the two should be unified in theory should be abandoned. The languages of poetic self-creation and democratic politics are, in fact, incommensurable;

1 The term "poets" is to be understood in a very broad sense: it is a category that includes not only artists, writers or even philosophers, but also revolutionary scientists and utopian political activists. In other words, it includes all those who contribute to the creation of certain 'languages' with their own criteria of truth. 
yet, it does not mean that the two corresponding projects of "public problem-solving" and "private struggles for autonomy" cannot coexist. ${ }^{2}$

Rorty's controversial solution is as follows. Irony and the aesthetic should be limited to the private sphere, while the public sphere would be dedicated to a reduction of suffering. Writers, like Nietzsche, Heidegger and Derrida, should be re-read as theorists of self-creation, but they have no utility for democratic politics, which had with John Stuart Mill its "last conceptual revolution”. Democratic politics would be working within the boundaries of the vocabulary of common sense-that is, they would focus solely on finding the best ways to diminish cruelty and would provide each of its members the freedom to articulate in their personal language a way of life that they may realise privately. Under the one condition that they do not seek to impose their personal visions on the whole of society in the name of public problem-solving, people ought to be able to indulge their wildest fancies in the private realm. In other words, the private realm is for private visions, the public realm is for the solving of public problems.

\section{First Line of Critique: The Distinction is Undesirable}

Let us now turn to the criticism this solution has faced. As mentioned in the introduction, the first line of criticism to be examined is that this private-public distinction would have unfavourable political consequences and is, therefore, undesirable. This critique will be examined in this section through its three major variations: (a) the feminist critique, (b) the liberal commitment problem and (c) the false consensus problem.

Feminist theorists provided some of the earliest critiques of Rorty's political project. This is perhaps not surprising, as the very idea of the separation of the public and private sphere in the liberal philosophical tradition is seen in feminism as oppressive to women. Catherine MacKinnon, for example, has pointed out that the "liberal ideal of privacy, the very splitting of the world into public and private, assumes that injuries arise in violating the private sphere, not within and by and because of it” ([10], p. 100). Rorty's feminist critics have argued that his separation of the public and the private ignores the insights of feminism and would turn the clock backwards on the realisations that the domestic is also political [8,11,12]. The claim that the public effort of diminishing cruelty and humiliation does not cross into the private sphere, it is argued, bodes very badly for women's liberation.

This feminist critique, I argue, arises from assigning the wrong meaning to Rorty's use of the words "public" and "private". Of course, Rorty does very little to assuage these concerns, as he fails to define these terms in CIS. In later years, however, he provides some hints to his intentions that might mitigate the feminist concerns. When asked about the feminist critique, Rorty responds that "I think [Nancy Fraser] and I were at cross purposes. I was thinking of one sense of private, something like Whitehead's definition of religion: 'what you do with your solitude.' Fraser was thinking of the private as the kitchen or bedroom, as opposed to the marketplace and the office. There was no relevance to what I was saying” ([13], pp. 61-62). ${ }^{3}$ Rorty’s point here is that in using “private” he was not referring

2 "There is no reason to think we have to choose between Dewey and Derrida, between public problem-solving and private struggles for autonomy. The two activities can coexist peacefully” ([9], p. 318).

3 See also this exchange in a later interview with Rorty: Q: Hasn't feminism awakened us to the danger of separating the public and private realms? RR: I guess I don't see the relevance of feminism here. The kind of private/public distinction 
to the classical liberal account of the term, but to something closer to Dewey's idea of the difference between public and private actions. In The Public and Its Problems, Dewey distinguishes between public actions, that is, actions that affect other people, and private actions that affect only the agents or that their effect on non-agents is considered insignificant $[15,16]$. While Rorty does not cite this work by Dewey in CIS or elsewhere, it is not implausible to posit that this is what he means by "private" and "public", especially as this definition sits well with the rest of his theory. The feminist critique, understood in this way, conflates the domestic and the private and is, therefore, irrelevant to Rorty's theory [17].

One might argue that this conceptual clarification still does not resolve the concerns of the feminist critique. Even when conceding to Rorty that his distinction is different from the public-domestic distinction, it is not clear that his pragmatism could be of use to feminist theory if the latter is taken to have a radical emancipatory role. If women are excluded from the public sphere, because the public sphere, in its practices and vocabulary, is constructed around the ideal of the white heterosexual male, then Rorty's insistence on "continuing the conversation” would do little to resolve their exclusion [11]. This is arguably a special case of the false consensus objection discussed below, so I will, therefore, address Rorty's so-called conservatism as a reply to that broader critique. Nevertheless, given that Rorty himself has devoted considerable efforts to persuade feminist theorists he was on their side, as well as the recently renewed interest in his writing among feminist theorists [18-20], it seems to me that it is relevant to mention an interpretation of Rorty that may clear him of the specific feminist objection.

How are the practices and vocabulary of the public sphere exclusionary to women? According to an influential feminist account, the idea of the public sphere in modern political theory and practice is inherently attached to the ideal of rational knowledge and the "man of reason”. This excludes women, as it idealises a certain mode of knowledge, which takes for granted gender inequalities-for example, bracketing away the role of care-and, as a result, categorises women as naturally irrational, therefore to be excluded from the public sphere. ${ }^{4}$ However, as Susan Dieleman has recently shown, this is not Rorty's account of rationality, and in fact, a considerable part of his philosophical project is an attempt to undermine the view that this form of rationality is "an ideal type of knowing that we all ought to possess or emulate” ([12], p. 898). I will not rehearse here Dieleman's arguments, but the point here is that Rorty does not endorse the account of rationality, which is the target of the radical feminist critique, and therefore, a feminist objection to his private-public distinction on those grounds does not hold. This is, of course, not the only argument available for feminists in criticising the distinction, although it is a very prominent one. Nevertheless and as mentioned above, the other possible routes seem to be a special case of the more general false consensus objection and are not unique to feminist theory.

the feminists mostly talk about is the distinction between who stays home and does the dirty work with the cooking and kids, and who gets out of the house into the great world outside. That has nothing to do with the distinction I'm trying to draw between individual self-creation and public responsibility. ([14], p. 31)

4 This is, admittedly, only a sketch of a serious and complex argument. I do not claim that my presentation of it here is exhaustive, only that it serves to make clear what account of rationality it is attacking. The interested reader may refer to Genevieve Lloyd's The Man of Reason [21] for a more detailed version of the above argument. 
The second variation of the argument against the desirability of Rorty's solution can be termed "the liberal commitment problem” [3,22-28]. Rorty urges us, it appears, to wholly devote the private sphere to self-perfection, which is private in the sense that it does not take other people into account. However, what guarantees, ask Rorty's critics, that this disposition will not find its way into the public sphere as well? There are two versions of this type of critique. First, it can be argued that as private self-creation requires constant redescription of one's final vocabulary, the liberal ironist would always be in doubt of the public language of liberalism and, therefore, never fully committed to it. A second, stronger claim argues it is more reasonable to portray the ironist as a cynical collaborator in whatever political language is around. The ironist might act as if she is committed to liberal society, as long as it happens to secure the best prospects for her to pursue her own private self-creation; yet, she will always remain "Nietzsche lurking behind a Millian mask” ([25], p. 25).

The first kind of criticism seems to me to be assuming that viewing one's final vocabulary as contingent is the same as to be radically sceptical about it. It is quite clear, however, that this is not Rorty's position. "To realize the relative validity of one's convictions and yet stand for them unflinchingly", he approvingly quotes Schumpeter, "is what distinguishes a civilized man from a barbarian” ([5], p. 46). As Michael Bacon convincingly argues, the Rortian ironist's doubts about her final vocabulary are not the kind of radical scepticism one finds in, say, Descartes. First, the liberal ironist can never doubt her whole vocabulary at the same time, as that would be meaningless. Second and more importantly, Rorty agrees with the classical pragmatists that such doubt only arises in a response to a particular problem and only where the ironist is faced with an alternative vocabulary that she sees as more useful. So, there is no reason to assume that the ironic attitude is incompatible with commitment [29]. What it does entail is the possibility of the ironist modifying her final vocabulary when faced with contradictions and counterarguments that cannot be resolved from within it. I cannot see, however, why this attitude should be of concern to those worried about liberal forms of political obligation, as surely, they will reject being blindly committed to a polity or a system of belief.

This solution, however, does not provide a satisfactory answer to the problem of cynicism presented by the second version of the critique. Rorty, when addressing this challenge, tends to dismiss it with counter-examples. Surely, he says, William James was just as ironic as Nietzsche, and Walt Whitman was as narcissistic as Ezra Pound. However, James and Whitman were, nevertheless, committed to liberal ideals, so it is possible to be both an ironist and a liberal $[13,30]$. However, simply pointing out the possibility of being both ironic and committed is hardly a convincing answer for the critic, who could argue that their endorsement of liberalism can just as adequately be described as cynical, as it just happen to coincide with their private projects and could just as easily be reversed when conditions change.

I would like to suggest, however, that Rorty would not necessarily see the cynical ironist as an acute problem for liberal society. In a sense, this is exactly the point of his distinction between the private and the public: we should not expect that a person's public and private vocabulary to be coherent with one another. As long as a person's actions and utterances in public are compatible with the values of liberal democracy — which are defined minimally as, first and foremost, the avoidance of cruelty—it should be of little concern to us (as liberals) what his private fantasies are. Our goal as political liberals is to create an increasingly attractive description of liberalism and its institutions, to demonstrate to those cynical about liberalism that it holds the greatest promise for their own self-creation. Some of 
them would, perhaps, eventually adopt the language of liberalism privately by the force of habit of using it publicly. ${ }^{5}$ However, even those who remain anti-liberal regardless of attempts at persuasionthose who Rorty terms "mad", like Nietzsche, Loyola or the Marquis de Sade-could still be accommodated, as long as their deviancy remains their own business [32]. Rorty's theory is that this sense is distinct from that of liberal perfectionists, as he is indifferent to people's private ethical selfcreation and places minimal constraints on their public morality. For those individuals whose private self-creation is incompatible with the public goal of diminishing cruelty and-importantly-try to manifest their fantasies of cruelty towards others, Rorty prefers social exclusion over state coercion, but the latter could be used when the first fails.

This answer leads us to the last line of argument against the desirability of Rorty's solution, which is in some ways the mirror image of the previous one. As shown, the "liberal commitment" critique argues that the public sphere could not be safeguarded from the narcissistic, cynical private sphere that Rorty advocates for as a source of self-creation. Yet a different line of criticism argues that the Rortian "segregation" solution does not leave enough space for interaction between the private and the public spheres. As he relegates all creative and idiosyncratic redescriptions to the private realm, Rorty does not allow criticism to influence the public discourse and, thus, sterilises the public sphere [23,33-35]. Rorty's manner of privatising critique is, according to this line of argument, what renders his political theory a conservative apologia for North American liberalism and the status quo. Rorty's utopia turns out to be one with "no public space" for debate and argument [23]. Chantal Mouffe argues that in his conception of the democratic public sphere, Rorty makes the same mistake as Habermas, falsely imagining it as the realm of consensus and harmony, rather than realising its agonistic and conflicting nature [35]. Certain strands of the feminist critique discussed above are, as I argued, private cases of this objection.

Admittedly, Rorty has done very little to prove his radical critics wrong. From his earlier remarks that "there is nothing wrong with liberal democracy", to his later attacks on the radical left, "the unpatriotic academy" and what he saw as "fashionable theories of ressentiment", Rorty seemed to affirm his belief that Mill's version of liberalism was the "last word" in Western political theory and that the United States is the nation most closely resembling the ideal of that theory [5,36]. When he applies his political theory to a discussion of concrete political questions, it certainly appears as if Rorty is arguing for nothing more than to make liberal values more inclusive and global, but not for a change in their content.

Yet, it would be a mistake to assume from Rorty's political commitments that his theory entails any specific final political structure. Indeed, if we accept Rorty's ideas about the contingency of language, there can never be such a thing as the last word, in political theory or in any other discourse. In a sense, Rorty's use of the word "final" in the term "final vocabulary" adds to this confusion, as it could be easily misunderstood as implying finality in a teleological sense. However, a close reading of Rorty can suggest that the language of liberal democracy—which happens to be his final vocabulary—should

5 "I see no better political rhetoric available than the kind that pretends that "we" have a virtue, even when we do not have it yet. That sort of pretense and rhetoric is just how new and better "we's" get constructed. For what people cannot say in public becomes, eventually, what they cannot say even in private, and then, still later, what they cannot even believe in their hearts” ([31], p. 726) (emphasis added). 
not be understood in this manner. As truth is to be understood as the result of a free discussion within a community, and the results of such discussion cannot be determined a priori; it is always possible that a new political vocabulary would appear and replace the liberal one.

It is true that Rorty's theory is wholly anti-radical in its interpretation of political pragmatism. The political vocabulary can change only in a piecemeal manner and only as a result of a non-coercive discussion and refinement of shared values in response to concrete problems. Only if acceptance of this view is meant by the term "conservatism" does it make sense to term Rorty's solution conservative. This, however, seems very different from the kind of political dogmatism of which his critics accuse him. Rorty views liberal democracy as a political system, which is optimal for the kind of free and open discussion he supports, but he is aware that future members of the community might look at our present society and see flaws and biases. For all of Rorty's rhetoric, it is important to see that he always qualifies his strong statements about the finality of liberalism, which is not always picked up by his critics. The full quote from CIS is "I think that contemporary liberal society already contains the institutions for its own improvement... My hunch is that western social and political thought may have had the last conceptual revolution it needs” ([5], p. 63). It is possible, therefore, to use Rorty's theory to argue against liberal democracy if one is able to show that a different system would be more effective in diminishing cruelty and suffering.

Rorty's criticism of the radical left could be understood in light of these views. In his notable political treatise, Achieving Our Country, he argues in favour of twentieth century social reformers, whose policies he interprets as working from within the existing conventions to reduce suffering and against the new left's tendency to move away from practical questions of resource distribution to questions of identity and recognition. This attitude shift from reformist to revolutionary is dangerous, argues Rorty, for two reasons. At best, with their refusal to work within existing public vocabulary, leftist intellectuals become irrelevant to actual politics, as “these futile attempts to philosophize one's way into political relevance are a symptom of what happens when a Left retreats from activism and adopts a spectatorial approach to the problems of its country” ([35], p. 94). At worst, revolutionary intellectuals are driven by an epistemological certainty in the truth of their ideals, which Rorty findsas seen above in his advocation of irony-as pernicious.

Some of Rorty's more radical critics will undoubtedly maintain, even when conceding the possibility for gradual reform in political institutions, that his theory remains overly conservative. This objection is significant, especially if we interpret Rorty as saying that while different descriptions of how to advance the ideals of liberalism are always accepted in the public sphere, the ideals themselves cannot be challenged. However, it seems to me that Rorty's theory is consistent with any change of the public vocabulary, including the most basic values and ideals, for which Rorty claims there could be no non-circular justification. The burden of justification for modifying this "final vocabulary" will be higher, of course, than for more peripheral beliefs, but that does not imply that they are beyond change. The main constraint on political change that Rorty insist on, as we saw above, is that it will be through non-coercive means. While this answer will not satisfy those who believe that substantial social change can only be brought about by revolutionary violence, I expect that it at least mitigate the concerns of the majority of Rorty's critics. 


\section{Second Line of Critique: The Distinction is Unattainable}

If my interpretation of Rorty in the previous section is correct, the objections to his notion of the private-public distinction on grounds of desirability, if not entirely dissolved, are at least considerably mitigated. Nonetheless, the solutions I have suggested raise a question of a different sort. It is unclear whether the distinction between the private and the public spheres is at all attainable, regardless of it being desirable or not. In fact, it has been shown that Rorty himself, when offering solutions to the problem of desirability, might be seen as undermining the possibility of the distinction. I argue that this is a more important challenge than the question of desirability that reveals why a reformulation of Rorty's private-public distinction is necessary.

Rorty's readers are often critical of the idea of "a firm distinction" between the public and the private, especially given Rorty's admiration of the pragmatism of John Dewey. Rorty explicitly accepts the Deweyan notion that the grand dichotomies of Western philosophy-subject/object, fact/value, theory/practice-are subject to historical contingencies, so it is peculiar that he chose to invoke such a rigid and ahistorical dichotomy himself $[14,23] .{ }^{6}$ If Rorty were working in a truly pragmatist fashion, argues Ernesto Laclau, he would seek to problematise and historicise this boundary, to "show it for what it really is: an ideal-typical attempt at stabilizing an essentially unstable frontier, which is constantly trespassed from two sides” ([37], p. 65).

Laclau's argument raises two interesting points for consideration. First, one can argue that Rorty's private self is in itself formed by the public language, and therefore, it makes no sense to talk about a wholly private, idiosyncratic language. As Richard Shusterman convincingly argues, even the language of the "strong" poet, those poets whose language is the most original, is based on a pre-existing public language [34,38]. This seriously questions the possibility of creating a wholly private vocabulary, of the kind Rorty's "strong poet” is described as creating. If the private language is founded and dependant on the public one, in what sense is it possible to claim that there is a separation between them?

The second point questions the distinction between private and public in terms of action. As we have seen in Rorty's response to the feminist critique, his formulation of the private and the public is based on a distinction between actions we carry out for ourselves (not worrying about their effects on others) and actions in which we do worry about such affects [39]. One of Rorty's favourite examples of using the vocabulary of the private sphere is writing: his reading of Derrida praises the latter for his playful, idiosyncratic style of writing, which is well-suited for the private purpose of self-creation, but has no place in the public discourse [5]. It remains unclear, however, if writing can be consigned to the sphere of the intellectual's private pleasure. It seems very odd to think of any writing, apart perhaps that of the private journal, as not having an effect on others. Derrida's, or, for that matter, Rorty's, so-called "private readings" have an intrinsic public status, which is highlighted by their authors' publishing and institutional affiliation. They do impose themselves on the public [22,38].

The two points above demonstrate that Rorty's solution cannot be understood as a “firm distinction” even on Rorty's own terms. The private cannot be fully protected from the public if we

6 Rorty's usual response is that the private-public distinction is not of the same type as the abstract, philosophical dichotomies Dewey was keen to overcome. 
accept the Rortian description of the self as one without a core, where socialisation goes "all the way down" [5]. The public cannot be defended from the private if we accept that the public language is always evolving by incorporating and literalising private metaphors. Some of Rorty's more sympathetic readers have suggested that these objections could be mitigated with a softer account of the distinction, allowing for more interaction between the public and the private [29,40]. Others have argued that Rorty had a change of heart in the years following CIS and drops the public-private distinction in his later writings [2,41].

My position on this point is that both suggestions are only partly right. I agree that Rorty's project is incoherent with an idea of rigid separation (if such separation is at all tenable) and that Rorty's later writings exemplify this kind of fluidity between the private and public sphere more clearly. However, it would be a mistake to think that this "softer" version of the distinction is different from what is suggested in CIS. As we have already seen in the previous section in regards to the critiques of political desirability, Rorty's positions on these questions make little sense if the private and the public are hermetically separated. Rorty's use of the adjective "firm" for the distinction in CIS is unfortunate, as it does not cohere with the way he describes the way it functions. It is far more useful, I argue, not to think of the private-public distinction as a sharp, distinct and ahistorical separation, but to reformulate it in a way that is more in line with the rest of Rorty's theory.

\section{Reformulating the Private-Public Distinction}

Rorty's later writings and interviews are a useful source for this reformulation of the public-private distinction. Perhaps, in light of criticism, he attempts to provide a more coherent description of the nature of the distinction. In his 1997 Spinoza lectures, Rorty argues that the private-public is not a dichotomy, but a spectrum. People, like Nietzsche and Heidegger, on the one hand, and the dull public bureaucrat, on the other, are representative of the two extremes of this spectrum. However, most of us are somewhere in the middle, and this is where the distinction comes in. "We are good citizens of a modern, pluralistic, democratic society precisely because we do not try to make all the parts of our lives fit together-and, in particular, because we do not insist that our fellow-citizens share our own symbols of ultimate concern, our own sense of the significance of our own lives” ([42], p. 28). In a later interview, we can find this important paragraph:

I didn't say everybody had a public/private split, but some people do... My public/private distinction wasn’t an explanation of what every human life is like. I was, instead, urging that there was nothing wrong with letting people divide their lives along the private/public line. We don't have a moral responsibility to bring the two together. It was a negative point, not a positive recommendation about how everybody should behave... We contain copresent, but distinct sets of equally coherent sets of desires. These may not always be able to be made coherent with one another, but they may not be any the worse for that. Plato was wrong: you don't have to get everything to get together ([13], pp. 62-63; [emphasis added]).

This seems to be in contrast with the view that Rorty's solution is a rigid and ahistorical dichotomy. How should we understand his private-public distinction in light of these comments?

My suggestion is that we should read the distinction as fluid and permeable, in more than one way. It should not be read, in the first instance, as a descriptive account of the self, i.e., "there exists a split 
between the private and the public self”, because such an ahistorical proposition is unacceptable on Rorty's own terms. One can think of hypothetical situations in which one's private desires and public persona coincide. A person devoted to her religion would not necessarily see a contradiction between her obligations to her society and her pursuit of salvation. Secondly, the private-public distinction should not be read as a prescriptive-normative account, i.e., "there should be a split between the private and the public languages". If that were true, there would be no place for the kind of innovative metaphors Rorty believes to be the source of moral progress.

Instead, Rorty's private-public distinction should be read as a moral possibility. Rorty, not providing a descriptive or normative account of the self, is making a therapeutic point. Mainstream Western philosophy, he would argue, has held the false idea that the private and the public should be conceptualised within one theory. Rorty's pragmatic account of the self offers an alternative picture. Our public and private vocabularies are nothing more than tools, which can be used for different purposes. Sometimes, the two vocabularies can coincide, just as different tools can be used for the same purpose. To write a letter, one can use both a pen and a pencil. However, it is important to remember that just because some tools can be used for the same specific purpose, it does not follow that all tools can be used for that specific purpose or that some tools can be used for all purposes. I think it is reasonable to say, as this analogy suggests, that Rorty's notion of the private-public does not mean that we should always separate the public and the private vocabularies. It does suggest that we should accept that sometimes and for some people, the two vocabularies do not serve the same purpose, and it is acceptable — in fact, better — to keep them apart. ${ }^{7}$

Rorty is not, therefore, suggesting a universal solution to all of humanity. His private-public distinction is intended as a solution to the problems posed, in a liberal society, by two groups of people. The first group, which I have discussed earlier, is that of the "mad”, i.e., people whose private vocabulary is not only different, but antithetical to public diminution of cruelty and cannot be persuaded otherwise. The private-public distinction, in the case of the people in this group-Nietzsche is Rorty's favourite example-is society's way of keeping them in check. By acknowledging the moral possibility of separating the public and the private, society can mitigate the danger the people of this group pose, while still allowing people to use "mad" innovative language in the pursuit of self-perfection. The exclusion of the "mad" from the public sphere has drawn considerable criticism towards Rorty, as it was interpreted as entailing the exclusion of minority views from the public sphere. More specifically, Rorty has been criticised for excluding all religious-based reasoning from the public sphere, forcing religious citizens into the position of the "mad". There is admittedly textual evidence that this was indeed Rorty's position regarding religious views, which he considered, at best, as private vocabularies and, in any case, “conversation-stoppers” in public deliberations [43,44]. This, however, does not seem to follow from the more charitable reading of the private-public distinction offered here. The religious citizen's view is not necessarily incompatible with the purposes of the liberal public sphere, at least not in the minimal sense in which Rorty interprets liberalism. While her

There is an interesting connection between Rorty's position on this point and John Rawls's argument in Political Liberalism for the separation of the public duties of justice and the private conceptions of the good. While this link is beyond the scope of this article, an argument for it could be found in Michael Bacon's Richard Rorty: Pragmatism and Political Liberalism [29]. 
justifications for her views might be fundamentally based on a belief beyond justification (e.g., the existence of God), that cannot be, on Rorty's own terms, a reason to exclude her from the conversation. Recall that any final vocabulary, not only the religious one, cannot be non-circularly justified. Rorty himself, I believe, has realised this inconsistency in his later writings and came to hold a much more moderate view, in which he objects not to religious reasoning as such, but to political religious organisations [45]. While this can still be viewed as an insufficient shift [46], I think it at least point to the kind of reformulation in the reading of the private-public distinction suggested in this article.

More interesting, I think, are Rorty's second target group. These are people who are in conflict between their personal idiosyncratic interests and obligation to the liberal creed. Unlike the members of the first group, whose private vocabulary is hostile to liberal democracy, the members of the second group are disturbed by the incoherence of their private and public languages. It seems to me that the people Rorty has in mind here are his fellow intellectuals and that the purpose of his theory is to provide a solution for this internal conflict. He wants to suggest that it is morally acceptable to separate intellectual scepticism from political obligation, that one can accept the contingent nature of language or debate the genealogy of morality and still be a useful member of society.

Some critics see this point to be elitist, as if Rorty is suggesting that only intellectuals can retain a critical, private language, while the rest should be conformists [8,34]. Again, Rorty does little to relieve this concern. When he describes his "liberal utopia", he proclaims that while everyone would be historicists and nominalists, only a few would be ironists, and it is clear that by these few, he thinks of the intellectual elite. Rorty seems to me to be overly narrow in stating his case, but I argue that his suggestion does necessarily connote elitism. If we take the private-public distinction to be a moral possibility, it is a possibility that is potentially available to everyone. Rorty's argument here is that it is impossible for all the members of society to be ironic about that society's values, and I think that this argument is greatly improved if we add "in the public sphere". Rorty is singling out intellectuals, because he thinks that it would be useful for society's moral progress for them-and only them-to question the public values and norms. I agree that public irony cannot be exercised by the whole of society at the same time, but I see no reason why this should be restricted to "intellectuals", unless we interpret this term very broadly. We cannot predict in advance who is going to provide the next innovative metaphor that will alter our public morality. Although it is true that philosophers, scientists, novelists and poets are more likely to have this kind of cultural effect, they are not its only source.

Yet, there is a further layer of complexity to be added. The idea of the private-public distinction, beyond suggesting a moral possibility, serves here as a way to keep public irony in check. We should understand it not as an intellectual privilege, but as a restriction. Rorty seems to believe that intellectuals are more liable to think that their own private creations-perhaps it is more useful to think of them as "theories" in this context-as having public utility, and therefore, his private-public distinction is not only a therapeutic point, but also a warning call. Rorty wants to keep his fellow intellectuals aware that their own private projects might be nothing, but private fantasies. While they might serve a public purpose, their application should be done with care and through persuasion and not through force, in keeping with the maxim of avoiding cruelty. 


\section{Conclusions}

My argument throughout this paper is that critiques of Rorty's private-public distinction have been mostly misdirected. Rorty's critics have taken him to suggest a rigid, hermetic separation between the private and public sphere and wanted to show how this solution would have negative political consequences, if it is at all attainable. Rorty's rhetoric in CIS no doubt adds to the confusion, but as his later writings show, this universal, strict distinction is not the only way in which his theory can be formulated. My formulation of Rorty's argument suggests that we think of his private-public distinction as a fluid and permeable one, applicable only in a particular context and to particular people. Private metaphors are constantly being deployed in the public discourse and some of themthose that make sense to others-may become part of the public language. It seems to me that when read in this manner, Rorty's argument is able to avoid the accusations of irresponsibility and conservatism. More than anything, it is a cautionary suggestion to his fellow intellectuals, perhaps summed up by "your theories might be the solutions to the nation's problems, but they might also just be your private fantasy. Either is fine, but don't confuse the two".

I opened this paper with Rorty's autobiographical “Trotsky and the Wild Orchids”, and now, this text seems germane in more than one way. Rorty described there his own intellectual journey to find a way to combine his private passions with his political obligations and found it in the idea of the divided self. However, this can now be read not only as the motivation for writing CIS, but also as the lens through, which it could be understood. It is relevant to note that the private-public distinction can also be seen as the solution to Rorty's problem and not only as a general one. Rorty admires Hegel, Nietzsche and Heidegger as philosophers, but criticises them for not realising that their books were nothing more than private experiments in self-creation [5]. It seems reasonable to understand Rorty's own project and, in particular, the private-public distinction, as such-not as a universal, all-encompassing theory about the nature of the self, but as a way to resolve a practical political problem in a pluralistic liberal society.

\section{Acknowledgments}

The author would like to thank Duncan Bell, Nick Martin, Agam Neiman, Julian Petri and Bjørn Ramberg, as well as the two anonymous reviewers for their helpful remarks. The author would also like to thank the Cambridge Overseas Trust, the UCL Overseas Research Scholarship and the Anglo-Israeli Association for their financial support.

\section{Conflict of Interest}

The author declares no conflict of interest.

\section{References and Notes}

1. Richard Rorty. "Trotsky and the Wild Orchids." In Philosophy and Social Hope. London: Penguin, 1999, 3-22.

2. Eric Gander. The Last Conceptual Revolution: A Critique of Richard Rorty's Political Philosophy. Albany: State University of New York Press, 1999. 
3. Charles Guignon, and David Hiley. "Biting the Bullet: Rorty on Private and Public Morality.” In Reading Rorty: Critical Responses to Philosophy and the Mirror of Nature (and Beyond). Edited by Alan Malachowski. Oxford: Blackwell, 1990, 339-64.

4. Richard Rorty. Philosophy and the Mirror of Nature. Princeton: Princeton University Press,1979.

5. Richard Rorty. Contingency, Irony, and Solidarity. Cambridge: Cambridge University Press, 1989.

6. Richard Rorty. “Unfamiliar Noises: Hesse and Davidson of Metaphor." Proceedings of the Aristotelian Society 61 (1987): 283-96.

7. Richard Rorty. “Non Reductive Physicalism.” In Objectivity, Relativism, and Truth. Cambridge: Cambridge University Press, 1991, 113-26.

8. Nancy Fraser. "Solidarity or Singularity? Richard Rorty Between Romanticism and Technocracy.” In Reading Rorty: Critical Responses to Philosophy and the Mirror of Nature (and Beyond). Edited by Alan Malachowski. Oxford: Blackwell, 1990, 303-22.

9. Richard Rorty. "Habermas, Derrida, and the Functions of Philosophy." In Truth and Progress. Cambridge: Cambridge University Press, 1998, 307-26.

10. Catharine MacKinnon. Feminism Unmodified: Discourses on Life and Law. Harvard: Harvard University Press, 1987.

11. Susan Bickford. "Why We Listen to Lunatics: Antifoundational Theories and Feminist Politics." Hypatia 8 (1993): 104-23.

12. Susan Dieleman. "Revisiting Rorty: Contributions to a Pragmatist Feminism.” Hypatia 25 (2010): 891-908.

13. Richard Rorty, Derek Nystrom, and Kent Puckett. Against Bosses, Against Oligarchies: A Conversation With Richard Rorty. Chicago: Prickly Paradigm, 2002.

14. Richard Rorty, and Eduardo Mendieta. Take Care of Freedom And Truth Will Take Care of Itself: Interviews With Richard Rorty. Stanford: Stanford University Press, 2006.

15. John Dewey. "The Public and Its Problems." In The Later Works of John Dewey, Volume 2, 1925-1953: 1925-1927, Essays, Reviews, Miscellany, and The Public and Its Problems. Edited by Jo Ann Boydston, and James Gouinlock. Carbondale: Southern Illinois University Press, 2008, 235-372.

16. Markar Melkonian. Richard Rorty's Politics: Liberalism at the End of the American Century. Amherst: Humanity Books, 1999.

17. Gideon Calder. Rorty's Politics of Redescription. Cardiff: University of Wales Press, 2007.

18. Richard Rorty. "Feminism and Pragmatism." In Truth and Progress. Cambridge: Cambridge University Press, 1998, 202-27.

19. Richard Rorty. "Feminism, Ideology, and Deconstruction: A Pragmatist View.” Hypatia 8 (1993): 96-103.

20. Marianne Janack, Ed. Feminist Interpretations of Richard Rorty. University Park: Pennsylvania State University Press, 2010.

21. Genevieve Lloyd. The Man of Reason: "Male" and "Female" in Western Philosophy. Minneapolis, MI: University of Minnesota Press, 1993.

22. Thomas McCarthy. “Ironist Theory as a Vocation: A Response to Rorty’s Reply.” Critical Inquiry 16 (1990): 644-55. 
23. Richard J. Bernstein. The New Constellation: The Ethical-Political Horizons of Modernity/Postmodernity. Boston: MIT Press, 1992.

24. Susan Haack. "Vulgar Pragmatism: An Unedifying Prospect." In Rorty \& Pragmatism: The Philosopher Responds to His Critics. Edited by Herman J. Saatkamp, Jr. Nashville: Vanderbilt University Press, 1995, 126-47.

25. Simon Critchley. "Deconstruction and Pragmatism-Is Derrida a Private Ironist or a Public Liberal?” In Deconstruction and Pragmatism. Edited by Simon Critchley, and Chantal Mouffe. London: Routledge, 1996, 19-42.

26. Howard Mounce. The Two Pragmatisms: From Peirce to Rorty. London: Routledge, 1997.

27. Alasdair MacIntyre. Dependent Rational Animals: Why Human Beings Need the Virtues. London: Duckworth, 1999.

28. John Horton. "Irony and Commitment.” In Richard Rorty: Critical Dialogues. Edited by Matthew Festenstein, and Simon Thompson. Cambridge: Polity, 2001, 15-28.

29. Michael Bacon. Richard Rorty: Pragmatism and Political Liberalism. Plymouth: Lexington Books, 2008.

30. Richard Rorty. "Response to Daniel Conway.” In Richard Rorty: Critical Dialogues. Edited by Matthew Festenstein, and Simon Thompson. Cambridge: Polity, 2001, 89-92.

31. Richard Rorty. "What Can You Expect from Anti-Foundationalist Philosophers? A Reply to Lynn Baker.” Virginia Law Review 78 (1992): 719-27.

32. Richard Rorty. "The Priority of Democracy to Philosophy.” In Objectivity, Relativism, and Truth. Cambridge: Cambridge University Press, 1991, 175-97.

33. Terence Ball, William Connolly, Peter Dews, and Alan Malachowski. "Review Symposium Richard Rorty.” History of the Human Sciences 3 (1990): 101-22.

34. Honi Haber. Beyond Postmodern Politics: Lyotard, Rorty, Foucault. London: Routledge, 1994.

35. Chantal Mouffe. "Deconstruction, Pragmatism and the Politics of Democracy." In Deconstruction and Pragmatism. Edited by Simon Critchley, and Chantal Mouffe. London: Routledge, 1996, 1-13.

36. Richard Rorty. Achieving Our Country: Leftist Thought in Twentieth-Century America. Cambridge: Harvard University Press, 1998.

37. Ernesto Laclau. "Deconstruction, Pragmatism, Hegemony.” In Deconstruction and Pragmatism. Edited by Simon Critchley, and Chantal Mouffe. London: Routledge, 1996, 47-68.

38. Richard Shusterman. Pragmatist Aesthetics: Living Beauty, Rethinking Art. Oxford: Rowman \& Littlefield, 2000.

39. Richard Rorty. "Response to Ernesto Laclau." In Deconstruction and Pragmatism. Edited by Simon Critchley, and Chantal Mouffe. London: Routledge, 1996, 69-75.

40. Daniel Conway. "Irony, State and Utopia: Rorty’s "We” and the Problem of Transitional Praxis." In Richard Rorty: Critical Dialogues. Edited by Matthew Festenstein, and Simon Thompson. Cambridge: Polity, 2001, 55-88.

41. Nancy Fraser. "From Irony to Prophecy to Politics: A Reply to Richard Rorty.” In Feminist Interpretations of Richard Rorty. Edited by Marianne Janack. University Park: Pennsylvania State Press, 2010, 47-54.

42. Richard Rorty. Truth, Politics and "Post-Modernism". Amsterdam: Uitgeverij Van Gorcum, 1997. 
43. Richard Rorty. "Religion as a Conversation-Stopper.” In Philosophy and Social Hope. London: Penguin, 1999, 168-74.

44. Richard Rorty. "Religious Faith, Intellectual Responsibility and Romance." In Philosophy and Social Hope. London: Penguin, 1999, 148-67.

45. Richard Rorty. "Religion in the Public Square: A Reconsideration”. Journal of Religious Ethics 31 (2003): 141-49.

46. Lauren Swayne Barthold. "Rorty, Religion and the Public-Private Distinction.” Philosophy \& Social Criticism 38 (2012): 861-78.

(C) 2013 by the author; licensee MDPI, Basel, Switzerland. This article is an open access article distributed under the terms and conditions of the Creative Commons Attribution license (http://creativecommons.org/licenses/by/3.0/). 